\title{
Cathepsin E (EC 3.4.23.34) - a review
}

\author{
Michał Chlabicz, Marek Gacko, Anna Worowska, Radosław Łapiński
}

\author{
Department of Vascular Surgery and Transplantology, Medical University of Bialystok, Poland
}

\begin{abstract}
Cathepsin E belongs to the third class of enzymes - hydrolases, a subclass of peptide bond hydrolases and a sub-subclass of endopeptidases with aspartic catalytic sites. Cathepsin $\mathrm{E}$ is an endopeptidase with substrate specificity similar to that of cathepsin D. In a human organism, cathepsin E occurs in: erythrocytes, thymus, dendritic cells, epithelial M cells, microglia cells, Langerhans cells, lymphocytes, epithelium of gastrointestinal tract, urinary bladder, lungs, osteoclasts, spleen and lymphatic nodes. In human cells, loci of the gene of pre-procathepsin $\mathrm{E}$ are located on chromosome 1 in the region 1231-32. The catalytic site of cathepsin $\mathrm{E}$ is two residues of aspartic acid - Asp96 and Asn281, occurring in amino acid triads with sequences DTG96-98 and DTG281-283. To date, no particular role of cathepsin E in the metabolism of proteins in normal tissues has been found. However, it is known that there are many documented pathological conditions in which overexpression of cathepsin E occurs. (Folia Histochemica et Cytobiologica 2011; Vol. 49, No. 4, pp. 547-557)
\end{abstract}

Key words: cathepsin E, cathepsin D

\section{Introduction}

Cathepsin E was first described in 1962 by Lapresle and Webb [1]. It belongs to the third class of enzymes - hydrolases, a subclass of peptide bond hydrolases and a sub-subclass of endopeptidases with aspartic catalytic sites. Cathepsin D, pepsin and renin belong to the same sub-subclass [2]. Initially, cathepsin E was described as a pepsin-like endopeptidase [3], a slowmoving proteinase [4] or erythrocyte membrane acid proteinase [5]. Later, it was proved immunochemically and biochemically, and confirmed thanks to the determination of the identical structure of the abovementioned endopeptidases, that all of them are the same enzyme - cathepsin E [4-7]. Cathepsin E is similar to cathepsin D. It differs from the latter, however, in that it has a broader substrate specificity, a lower optimum $\mathrm{pH}(2.5-2.8)$, it occurs in different cell organelles and occurs only in some kinds of cells and tissues [2]. The differences between cathepsin E and cathepsin $\mathrm{D}$ are summarized in Table 1.

Correspondence address: M. Chlabicz, Dept. of Vascular Surgery and Transplantology, Medical University of Bialystok, M. Sklodowskiej-Curie Str. 24a, 15-276 Bialystok, Poland; tel.: (+ 48 85) 74682 77, fax: (+ 48 85) 74688 96;

e-mail:chmichal@op.pl

\section{Distribution}

In human and animal organisms, cathepsin E occurs only in some cells, tissues and organs, and the cells, tissues and organs differ depending on the particular animal species [8]. In a human organism, cathepsin E occurs in: erythrocytes, thymus, dendritic cells, epithelial M cells, microglia cells, Langerhans cells, lymphocytes, epithelium of gastrointestinal tract, urinary bladder, lungs, osteoclasts, spleen and lymphatic nodes [9-14]. However, it does not occur in human neutrophiles or bovine erythrocytes [15] (Table 2). The content of cathepsin $\mathrm{E}$ in various rat tissues is presented in Table 3. The intracellular transport and distribution of cathepsin $\mathrm{E}$ are also very distinctive. Unlike pepsin and renin, this peptidase is not secreted to the lumen of the digestive tract, and is not directed to lysosomes like cathepsin D. Its characteristic place of occurrence is endoplasmic reticulum and Golgi apparatus $[10,16]$. Only in erythrocytes does it occur on the cytoplasmic surface of cell membrane [17].

\section{The gene encoding cathepsin $\mathbf{E}$}

In human cells, loci of the gene of pre-procathepsin $\mathrm{E}$ are located on chromosome 1 in the region 1231-32 [18]. The gene of cathepsin E comprises nine exons. 
Table 1. Differences between cathepsin E and cathepsin D

\begin{tabular}{|l|l|l|}
\hline Distinctive feature & Cathepsin E & Cathepsin D \\
\hline Encoding gene & Chromosome 1, region 1q31-32 & Chromosome 11, region 11p15.5 \\
\hline Molecular weight (mature form) & 82 & 46 \\
\hline Optimum pH in acting toward hemoglobin & $2.0\left(\right.$ temp. $\left.45^{\circ} \mathrm{C}\right)$ & 3.5 (temp. $\left.37^{\circ} \mathrm{C}\right)$ \\
\hline $\begin{array}{l}\text { Phosphorylation of mannose residues } \\
\text { to mannose-6-phosphate }\end{array}$ & No occurrence & Occurrence \\
\hline Molecular location & Plasma membranes, endoplasmic reticulum & Lysosomes \\
\hline $\begin{array}{l}\text { Activity inhibited by inhibitor from } \\
\text { human ascaris }\end{array}$ & Inhibition & No inhibition \\
\hline Protein substrate & Human albumin & Bovine globin \\
\hline Specific polypeptide substrate & Substance P & $\beta$-endorphin \\
\hline Antigenic characteristics & Various & Various \\
\hline
\end{tabular}

Table 2. Distribution of cathepsin E in mammalian blood cells, as revealed by a combined application of elctrophoretic and immunochemical methods

\begin{tabular}{|l|c|c|c|}
\hline & PMN* & MNL** & $\begin{array}{c}\text { Erythrocyte } \\
\text { ghost }\end{array}$ \\
\hline Human & - & - & + \\
\hline Rat & + & + & + \\
\hline Guinea pig & + & + & - \\
\hline Pig & - & - & - \\
\hline Cow & - & - & - \\
\hline Goat & - & - & - \\
\hline
\end{tabular}

*Polymorphonuclear leukocytes; **Mononuclear leukocytes

It encodes the signal peptide, propeptide and the active part of cathepsin E. Expression of the encoding gene and occurrence of cathepsin $E$ is limited to specific cells [19]. In some human cells, splicing variants of mRNA, participating in cathepsin E synthesis, have been discovered [20-23]. Splicing results in the removal of exon 7, which encodes the Asp40 residue in the fragment -Asp40-Thr41-Gly42- of the second active center [23]. The monomeric, unstable form of cathepsin E occurs in gastric carcinoma cells [24]. By means of recombination, a mutated form of cathep$\sin \mathrm{E}$ has been obtained, in which the unique Cys4 residue is substituted with Ala or Ser residue [25]. Mutated cathepsin E is less stable than natural cathepsin E, but its activity and sensitivity to inhibitors remains unchanged.

\section{Biosynthesis}

Cathepsin $\mathrm{E}$ is synthesized as a pre-proenzyme made up of 438 amino acid residues. Cleavage of an 18-amino acid propeptide results in the creation of procathe-
Table 3. Levels of cathepsin $E$ in various rat tissues

\begin{tabular}{|c|c|}
\hline Sources & $\begin{array}{c}\text { Cathepsin E } \\
{[\mu \mathrm{g} / \mathrm{mg} \text { of protein }]}\end{array}$ \\
\hline $\begin{array}{l}\text { Brain tissues } \\
\text { Cerebral cortex } \\
\text { Cerebellum } \\
\text { Hippocampus } \\
\text { Neostriatum }\end{array}$ & $\begin{array}{l}0.0004^{*} \\
0.0037^{*} \\
0.0017^{*} \\
0.0005^{*}\end{array}$ \\
\hline $\begin{array}{l}\text { Gastrointestinal tracts } \\
\text { Stomach } \\
\text { Jejunum } \\
\text { Colon } \\
\text { Esophagus } \\
\text { Liver }\end{array}$ & $\begin{array}{c}1.05\left(1.130^{*}\right) \\
0.03 \\
0.10 \\
\text { ND } \\
\text { ND }\end{array}$ \\
\hline $\begin{array}{l}\text { Lymphoid tissues } \\
\text { Cervical lymph node } \\
\text { Thymus } \\
\text { Spleen } \\
\text { Bone marrow }\end{array}$ & $\begin{array}{l}0.18 \\
0.19 \\
0.18 \\
0.13\end{array}$ \\
\hline $\begin{array}{l}\text { Urinary organs } \\
\text { Urinary bladder } \\
\text { Kidney }\end{array}$ & $\begin{array}{c}0.19 \\
0.005\end{array}$ \\
\hline $\begin{array}{l}\text { Secretory tissues } \\
\text { Submandibular gland } \\
\text { Lacrymal gland } \\
\text { Adrenal }\end{array}$ & $\begin{array}{l}0.006 \\
\text { ND } \\
\text { ND }\end{array}$ \\
\hline $\begin{array}{l}\text { Blood cells } \\
\text { Erythrocytes } \\
\text { Lymphocytes } \\
\text { Platelets } \\
\text { Peritoneal neutrophiles }\end{array}$ & $\begin{array}{c}0.002 \\
0.09 \\
0.004 \\
0.10\end{array}$ \\
\hline $\begin{array}{l}\text { Organs } \\
\text { Lung } \\
\text { Heart } \\
\text { Skeletal muscle } \\
\text { Skin }\end{array}$ & $\begin{array}{c}0.03(0.04 *) \\
\text { ND }\left(0.0012^{*}\right) \\
\text { ND } \\
0.03\end{array}$ \\
\hline
\end{tabular}

*Values from ELISA; ND — not detectable 
Table 4. Amino acid composition of signal peptide, propeptide, procathepsin E and cathepsin E of a human

\begin{tabular}{|c|c|c|c|c|}
\hline Amino acid & Signal peptide & Propeptide & Procathepsin E & Cathepsin E \\
\hline Ala A & 1 & 2 & 21 & 19 \\
\hline $\operatorname{Arg} R$ & 0 & 5 & 9 & 4 \\
\hline Asn N & 0 & 1 & 13 & 12 \\
\hline Asp D & 0 & 1 & 21 & 20 \\
\hline Cys C & 0 & 0 & 7 & 7 \\
\hline Gln $Q$ & 1 & 3 & 23 & 20 \\
\hline Glu E & 1 & 1 & 14 & 13 \\
\hline Gly G & 0 & 1 & 40 & 39 \\
\hline His $\mathrm{H}$ & 0 & 3 & 8 & 5 \\
\hline Ile I & 0 & 1 & 20 & 19 \\
\hline Leu L & 10 & 6 & 29 & 23 \\
\hline Lys K & 1 & 4 & 9 & 5 \\
\hline Met M & 1 & 1 & 10 & 9 \\
\hline Phe F & 0 & 2 & 21 & 19 \\
\hline Pro $\mathrm{P}$ & 0 & 2 & 25 & 23 \\
\hline Ser S & 0 & 5 & 40 & 35 \\
\hline Thr T & 1 & 0 & 22 & 22 \\
\hline Trp W & 0 & 1 & 5 & 4 \\
\hline Tyr Y & 0 & 0 & 13 & 13 \\
\hline Val V & 2 & 1 & 30 & 29 \\
\hline Number of amino acid residues & 18 & 40 & 420 & 380 \\
\hline Molecular weight (Da) & 2,307 & 5,344 & 47,560 & 42,215 \\
\hline
\end{tabular}

psin E. The molecular weight of procathepsin $\mathrm{E}$ is 90,000 Da. It is a homodimer containing an intramolecular -S-S- bridge. In acidic $\mathrm{pH}$, auto-activation of procathepsin E, cleavage of a 40-amino acid propeptide and creation of the mature form of cathepsin $\mathrm{E}$ occurs, as presented in Table 4 and Figure 1 [26].

The propeptide has a strong positive charge, as it contains five residues of alkaline amino acids and only two residues of acidic amino acids. Hence a hypothesis arises that the propeptide binds to the active form mostly by electrostatic effect. Thanks to that, procathepsin $\mathrm{E}$ is prone to auto-activation after a short time in acidic $\mathrm{pH}$, as a result of which it is transformed into the mature form. The mature form is made up of 380 amino acid residues and its molecular weight is $42 \mathrm{kDa}$ [27], (Figure 2). The catalytic site is made up of Asp98, Asp283 and Thr284 (DTG) residues [27] (Figure 3). The -S-S- bridge between two residues Cys34 in the N-terminus of the molecule results in a homodimer appearing. The -S-S- bridge is responsible for the stability of that peptidase in neutral $\mathrm{pH}$. Thanks to that, the active site is made up of two homologous domains, containing sequences of tripeptide DTG [2]. The two domains comprise the active
AQGSLHRVPLRRHPSLKKKLRARSQLSEFWKSHNLDMIOF

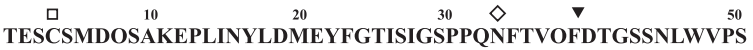
VYCTSPACKTHSRFQPSQSSTYSQPGQSFSIQYGTGSLSGIIGADQVSVE $\stackrel{110}{120} \stackrel{130}{130} \stackrel{140}{150}$ ${ }^{160}{ }_{\text {QNLVDLPMFSVYMSSNPEGGAGSELIFGGYDPSHFSGSLNWVPVTKQAYW }}^{1700}$ $\stackrel{210}{210} \stackrel{220}{20}{ }^{230}{ }^{230}{ }^{240}{ }^{250}$

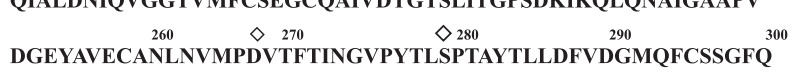
GLDIHPPAGPLWILGDVFIRQFYSVFDRGNNRVGLAPAVP $^{330}$

Figure 1. Alignment of the deduced amino acid sequences of procathepsin E from human. The sequence for the murine procathepsin $\mathrm{E}$ is given in full. At any given position where no residue is shown, sequence identity with murine procathepsin E exists. The positions of the active sites aspartic acid residues, potential $\mathrm{N}$-linked glycosylation sites and the Cys residue involved in the formation of the interchain disulfide bridge are indicated by $\mathbf{\nabla}, \diamond$ and $\_$respectively

site. The DTG sequence occurs in cathepsin E molecules in humans and all animal species except rabbit cathepsin E [28].

A molecule of cathepsin $\mathrm{E}$ is $\mathrm{N}$-glycosylated by connecting high-mannose oligosaccharides or com- 


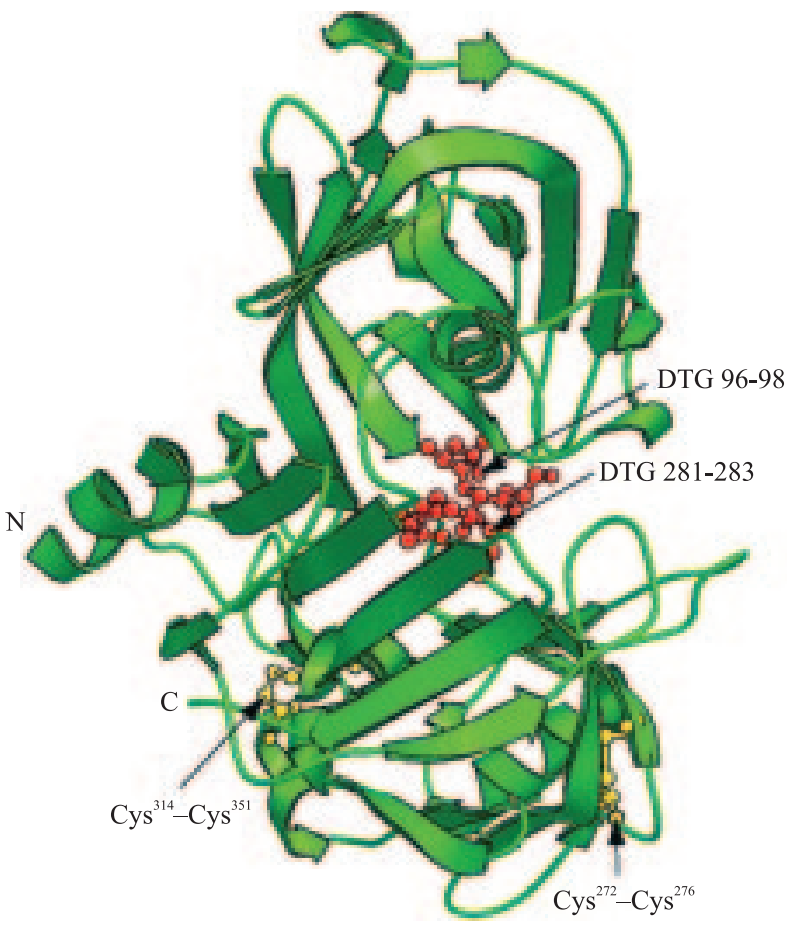

Figure 2. The computed structure of cathepsin E. The main chain is shown by ribbon drawing. The residues at the DTG/DTG active site and those involved in forming disulfide bonds are shown with ball-and-stick drawing; the former is colored red and the latter yellow

plex oligosaccharides [29]. The sites of glycosylation are Asn residues. Cathepsin E of gastric mucosa contains high-mannose oligosaccharides, while cathep$\sin \mathrm{E}$ of human erythrocytes contains complex oligosaccharides [10, 30, 31].

Neither activation of procathepsin E nor its sensitivity to inhibitors is dependent on the presence or type of oligosaccharides. Glycosylation does not affect the stability of cathepsin $\mathrm{E}$ in low $\mathrm{pH}$ either. Still, the oligosaccharide component increases its stability in neutral $\mathrm{pH}$ and its immunity to higher temperature. ATP participates in stabilizing cathepsin E in $\mathrm{pH} 7.0$ [32].

\section{Purification}

In order to obtain a highly purified preparation of cathepsin E, we first need to find a tissue including the greatest amounts possible of that peptidase. Differences in enzyme and protein composition of cells and tissues necessitate individual preparation solutions. In the preliminary phases of cathepsin E purification, methods commonly used for isolation and purification of proteins are applied, such as isoelectric point precipitation, ammonium sulphate and organic solvents fractionation, Sephadex gel molecular

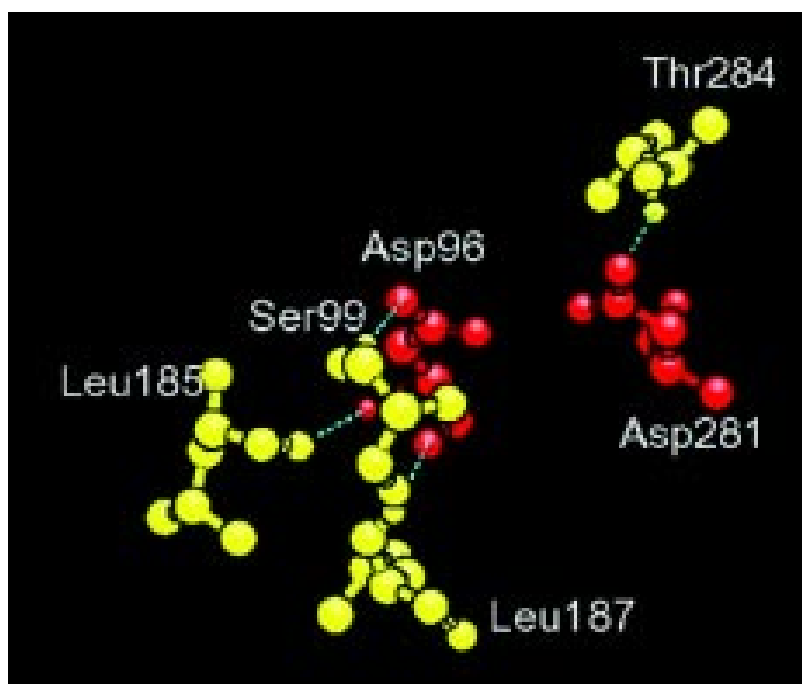

Figure 3. Place of activity of cathepsin E

filtration, ion-exchange chromatography on DEAE-cellulose, ConA sepharose or FPIC Mono Q column [2]. The final phases of purification are affinity chromatography on agarose bound to pepstatin or to an antibody against cathepsin E [2]. A homogenous preparation of mature cathepsin $\mathrm{E}$ has been obtained from human gastric mucus [4], human erythrocytes [33] and rat spleen [34], neutrophiles [35] and epidermis [36]. Cathepsin E preparations are kept at $-20^{\circ} \mathrm{C}$, in buffer with pH 7.0 containing $50 \%$ glycerol.

Obtaining a highly purified preparation of procathepsin $\mathrm{E}$ is difficult, as affinity chromatography cannot be used [37,38]. Procathepsin E was obtained by means of recombination from bacteria $E$. Coli [39, 40]. Recombinant human cathepsin $E$ has also been purified from ovaries of Campbell's dwarf hamster [41] and from Pichia pastoris [42]. Procathepsin E is auto-activated in acidic $\mathrm{pH}[2,43]$.

\section{Specificity of activity}

Cathepsin E is an endopeptidase with substrate specificity similar to that of cathepsin D. It expresses high affinity to hydrophobic amino acid residues in $\mathrm{P} 1$ and P1' positions of substrates [44]. In $\mathrm{P} 2$ position, unlike cathepsin D, there may be a residue of lysine [45]. In P2' position, there is a broad structural spectrum of amino acid residues, including residues of polar amino acids [46]. In an oxidized $B$ chain of bovine insulin, cathepsin E cleaves the peptide bond presented in Figure 4. Only the first of these bonds is not cleaved by cathepsin D. Cathepsin E cleaves six peptide bonds in the B chain of insulin. Specificity of cathepsin E has also been tested on proteins: tetanus toxin [47], glycoprotein and mellitin from bee venom [48-50]. 


\section{Mechanism of activity}

The catalytic site of cathepsin $\mathrm{E}$ is two residues of aspartic acid - Asp96 and Asn281, occurring in amino acid triads with sequences DTG96-98 and DTG281-283. Carboxyl groups of amino acid residues activate a water molecule and act as proton donors and acceptors. The Asp96 carboxyl group is dissociated and the Asp281 carboxyl group is not. The dissociated Asp96 carboxyl group activates a water molecule and enables the release of a proton from it. As for the non-dissociated Asp281 carboxyl group, it polarizes the carboxyl group of peptide bond, facilitates the creation of tetraedric intermediate and enables the cleavage of that compound (Figure 5). After binding the substrate, two simultaneous transition reactions occur. The first reaction is transition of the proton from a water molecule to the carboxyl anion Asp96 and from the carboxyl group Asp281 to oxygen of the carboxyl group of the substrate. That results in creating a tetraedric intermediate. In the other reaction, peptide bonds are moved from the intermediate to the carboxyl ion Asp96 and from the carboxyl group Asp281 to the nitrogen atom. It causes hydrolysis of the substrate's peptide bond, appearance of the first product of reaction with a free carboxyl group and the second product of reaction with a free amino group, as well as recreation of the initial structure of the catalytic site of cathepsin E. Since those reactions are conducted by dissociating carboxyl groups of the catalytic site, the speed of the processes depends greatly on the $\mathrm{pH}$ of the environment. Cathepsin $\mathrm{E}$ is active in acidic environments with $\mathrm{pH}$ from 2.5 to 5.5 .

\section{Inhibitors}

Diaso-acetyl-norleucine methyl ester is a synthetic inhibitor of cathepsin E, and the reaction is catalyzed

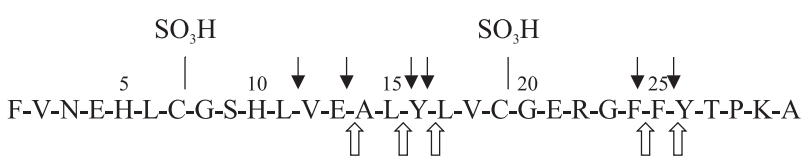

Figure 4. Peptide bonds cleaved in B chain of bovine insulin by cathepsin $\mathrm{E}$ and cathepsin $\mathrm{D}$

$\downarrow-$ place of activity of cathepsin E; $\uparrow$ - place of activity of cathepsin D with $\mathrm{Cu}^{2+}$ ions [51]. The chemical formula of that inhibitor is presented in Figure 6. The compound also inhibits the activity of cathepsin D.

A group inhibitor of aspartic endopeptidases (cathepsin E, cathepsin D, pepsin and renin) is pepstatin A [52] and its derivatives: acetyl- and isovaleryl-pepstatin [44, 53, 54] (Figure 7) [17].

An inhibitor of cathepsin $E$ with narrow specificity is a polypeptide inhibitor isolated from human ascaris $[4,7,39,55]$. It does not inhibit cathepsin D activity; however, it inhibits pepsin activity. Its molecular weight is about $17,000 \mathrm{Da}$. It is synthesized as an inactive form. At the N-terminus of the molecule, there is an amino acid sequence composed of 20 amino acid residues, cleaved off at activation; that is a signal propeptide. The active inhibitor is made up of 149 amino acid residues. It includes five Cys residues in positions 13, 48, 59, 79 and 146; it has three disulphuric bridges: Cys13-Cys59, Cys48-Cys66 and Cys79-Cys146. It has also been obtained by means of genetic recombination [56, 57]. The amino acid composition of that inhibitor is presented in Table 5, and the amino acid sequence in Figure 8 [58].

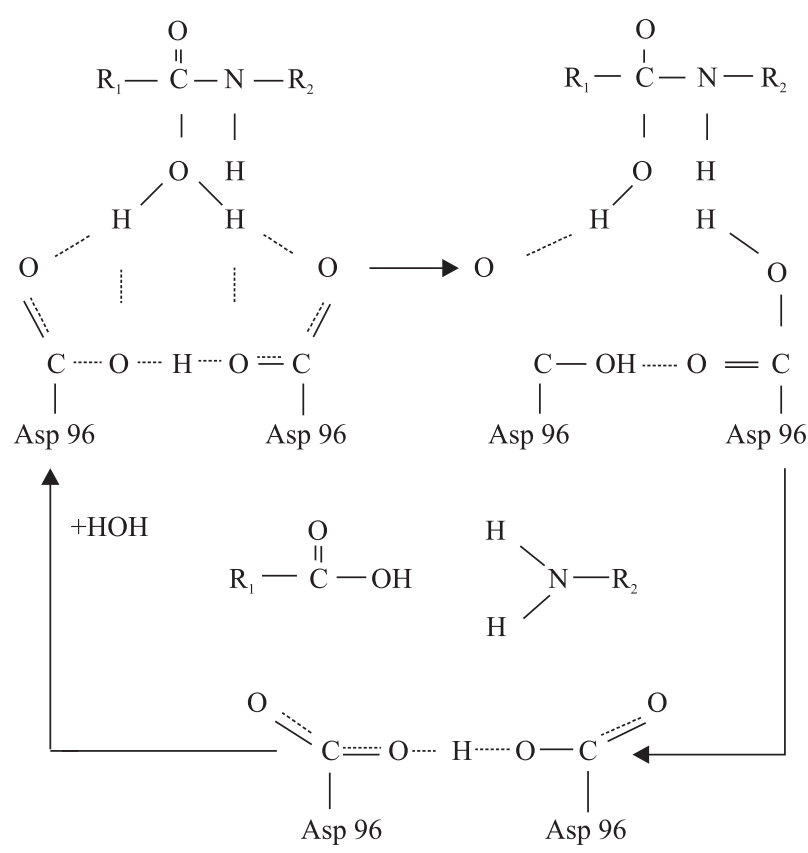

Figure 5. Diagram of peptide bond clevage by cathepsin E

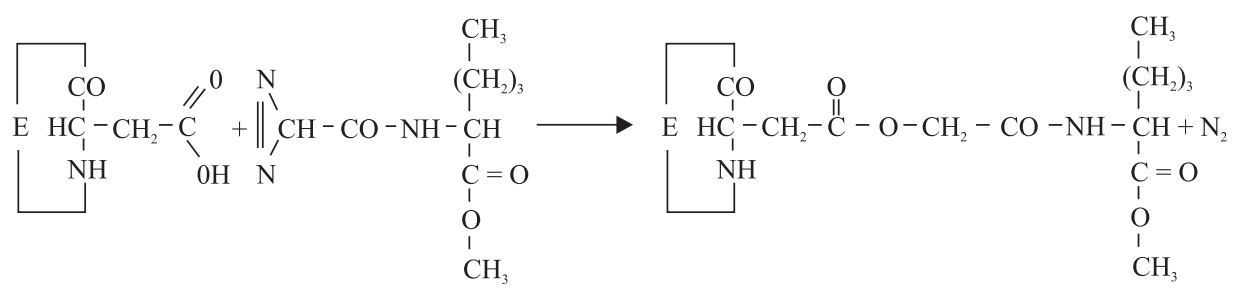

Figure 6. Reaction of cathepsin E with diaso-acetyl-D, L norleucine methyl ester 


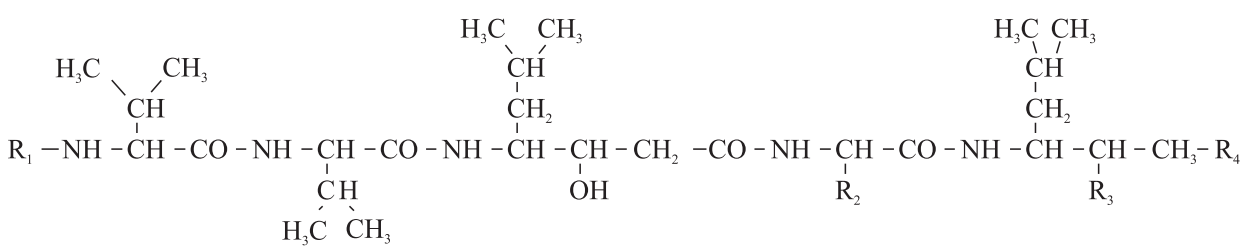

\begin{tabular}{|l|c|c|c|c|}
\hline Pepstatins & $\mathbf{R}_{1}$ & $\mathbf{R}_{2}$ & $\mathbf{R}_{3}$ & $\mathbf{R}_{4}$ \\
\hline A & iso-valeryl & $-\mathrm{CH}_{3}$ & $-\mathrm{OH}$ & $-\mathrm{COOH}$ \\
\hline B & n-caproyl & $-\mathrm{CH}_{3}$ & $-\mathrm{OH}$ & $-\mathrm{COOH}$ \\
\hline C & iso-caproyl & $-\mathrm{CH}_{3}$ & $-\mathrm{OH}$ & $-\mathrm{COOH}$ \\
\hline D & n-heptanoyl & $-\mathrm{CH}_{3}$ & $-\mathrm{OH}$ & $-\mathrm{COOH}$ \\
\hline E & iso-heptanoyl & $-\mathrm{CH}_{3}$ & $-\mathrm{OH}$ & $-\mathrm{COOH}$ \\
\hline F & anteiso-heptanoyl & $-\mathrm{CH}_{3}$ & $-\mathrm{OH}$ & $-\mathrm{COOH}$ \\
\hline G & n-capryl & $-\mathrm{CH}_{3}$ & $-\mathrm{OH}$ & $-\mathrm{COOH}$ \\
\hline H & iso-capryl & $-\mathrm{CH}_{3}$ & $-\mathrm{OH}$ & $-\mathrm{COOH}$ \\
\hline Hydroxypepstatine A* & iso-valeryl & $-\mathrm{CH}_{2}-\mathrm{OH}$ & $-\mathrm{OH}$ & $-\mathrm{COOH}$ \\
\hline Pepstanone A* & iso-valeryl & $-\mathrm{CH}_{3}$ & $=\mathrm{O}$ & $-\mathrm{H}$ \\
\hline
\end{tabular}

Figure 7. Structure of pepstatins, hydroxypepstatin and pepstanones. * — acyl radical $\mathrm{R}_{1}$ — the same as pepstatins A-H

Table 5. Amino acid sequence of cathepsin E inhibitor from human ascaris

\begin{tabular}{|c|c|c|c|}
\hline Amino acid & Signal peptide & Proinhibitor & Mature form \\
\hline Ala A & 2 & 17 & 15 \\
\hline $\operatorname{Arg} R$ & 0 & 9 & 9 \\
\hline Asn $\mathrm{N}$ & 0 & 7 & 7 \\
\hline Asp D & 0 & 18 & 18 \\
\hline Cys C & 0 & 16 & 16 \\
\hline Glu E & 0 & 10 & 10 \\
\hline $\mathrm{Gln} Q$ & 0 & 10 & 10 \\
\hline Gly G & 0 & 6 & 6 \\
\hline His $\mathrm{H}$ & 1 & 13 & 12 \\
\hline Ile I & 2 & 8 & 6 \\
\hline Leu L & 4 & 8 & 4 \\
\hline Lys $\mathrm{K}$ & 0 & 7 & 7 \\
\hline Met M & 1 & 2 & 1 \\
\hline Phe F & 0 & 12 & 12 \\
\hline Pro P & 0 & 3 & 3 \\
\hline Ser $S$ & 5 & 14 & 9 \\
\hline Thr T & 1 & 4 & 3 \\
\hline Trp W & 2 & 3 & 1 \\
\hline Tyr Y & 1 & 1 & 0 \\
\hline Val V & 1 & 1 & 0 \\
\hline Number of amino acid residues & 20 & 169 & 149 \\
\hline Molelcular weight (Da) & 18,658 & 2,262 & 16,396 \\
\hline
\end{tabular}




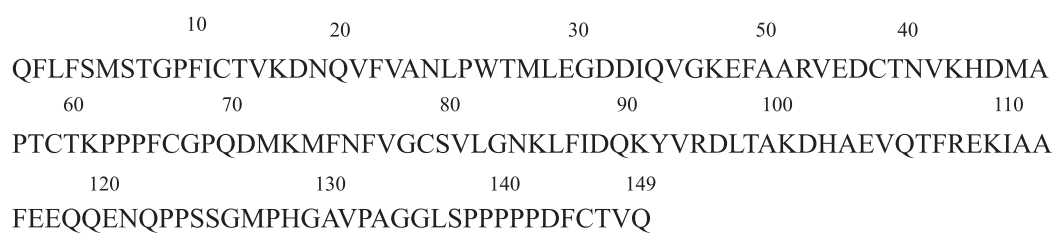

Figure 8. Amino acid sequence of cathepsin $\mathrm{E}$ inhibitor from human ascaris

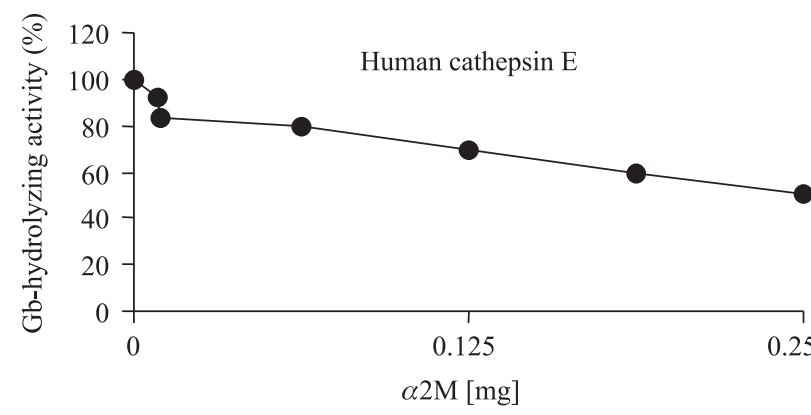

Figure 9. Effect of bovine $\alpha 2 \mathrm{M}$ on the proteolytic avtivities of cathepsin E. The Gb-hydrolyzing activity of cathepsin E purified from human erythrocytes was measured at $\mathrm{pH} 3.8$ in the absence or presence of increasing amounts of $\alpha 2 \mathrm{M}$

Table 6. Complexes of cathepsin $\mathrm{E}$ with a polypeptide inhibitor, $\alpha 2$-macroglobulin and a specific antibody

\begin{tabular}{|l|l|}
\hline Inhibitor & Complex characteristics \\
\hline $\begin{array}{l}\text { Polypeptide } \\
\text { inhibitor }\end{array}$ & $\begin{array}{l}\text { Hydrophobic and ionic interaction } \\
\text { of catalytic site with reactive site of the } \\
\text { inhibitor, blocking of catalytic site }\end{array}$ \\
\hline$\alpha 2$-macroglobulin & $\begin{array}{l}\text { Limited proteolysis and conformation } \\
\text { changes of } \alpha 2 \text {-macroglobulin, creating } \\
\text { a spatial block for macromolecular } \\
\text { substrates }\end{array}$ \\
\hline $\begin{array}{l}\text { Antibodies against } \\
\text { cathepsin E }\end{array}$ & $\begin{array}{l}\text { Noncovalent bond of the antibody with } \\
\text { cathepsin E, blocking of cathepsin } \\
\text { catalytic site }\end{array}$ \\
\hline
\end{tabular}

Cathepsin E activity is also inhibited by a polyvalent endopeptidases inhibitor: alpha2-macroglobulin [59, 60] (Figure 9). Cathepsin E cleaves the -F811-L812-C peptide bond in the structure of that inhibitor.

A specific cathepsin $\mathrm{E}$ inhibitor is antibodies against that endopeptidase [52]. They allow for unambiguous differentiation between the activity of cathepsin $\mathrm{E}$ and cathepsin $\mathrm{D}$ found in a mixture (Table 6). It is illustrated in Figure 10, presenting inhibition of equimolar concentrations of those cathepsins found in the mixture.

Differences in sensitivity of cathepsin E, cathep$\sin \mathrm{D}$, pepsin and renin to inhibitors are presented in Table 7.
1.
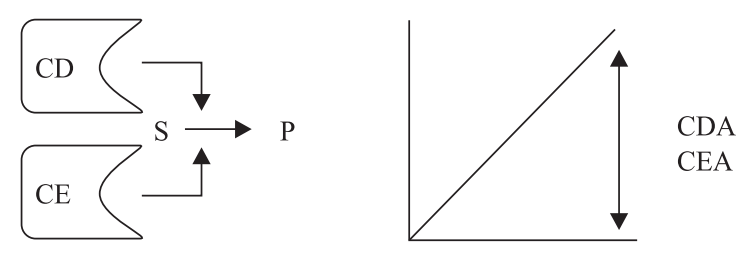

2.
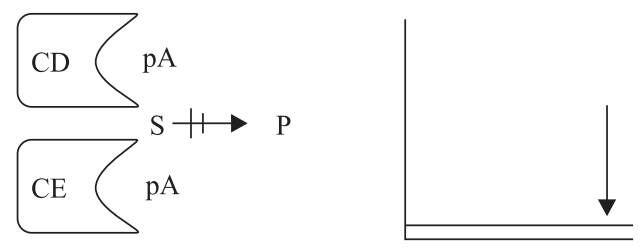

CDJ

CEJ

3.
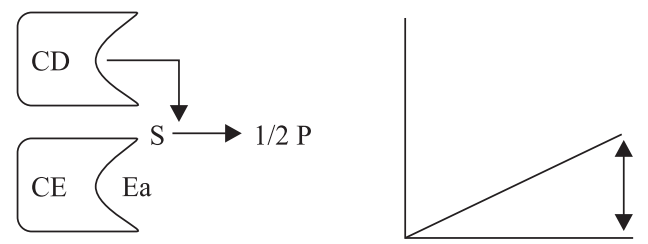

CDA

4.
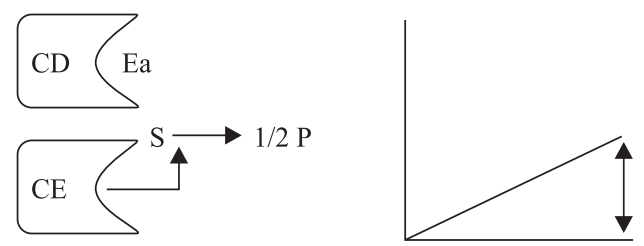

CEA

Figure 10. Principle of measurement of activity of cathep$\sin \mathrm{E}(\mathrm{CE})$ and cathepsin $\mathrm{D}(\mathrm{CD})$ in equimolar mixture: 1 - total activity of CDA and CEA, 2 - inhibition of activity of both cathepsins by pepstatin $\mathrm{A}(\mathrm{pA})$, 3 - inhibition of cathepsin E by specific antibodies (CDA), 4 - inhibition of cathepsin $\mathrm{D}$ by specific antibodies (CEA). Based on a publication by Zaidi and Kalbachero [52]

\section{Determination of activity and concentration}

Cathepsin E is an endopeptidase similar in specificity to cathepsin D. Both of them decompose, among others, blood serum albumin and globin. Yet, albu$\mathrm{min}$ is a substrate more specific for cathepsin E, and globin for cathepsin D [62-64] (Table 8). 
Table 7. Vulnerability of human aspartyl proteases to inhibitors

\begin{tabular}{|l|c|c|c|c|}
\hline Inhibitor* & Cathepsin E & Cathepsin D & Pepsin & Renin \\
\hline Pepstatin A & + & + & + & + \\
\hline Ascaris sp.derived inhibitor & + & - & + & - \\
\hline Antibodies against cathepsin E & + & - & - & - \\
\hline Antibodies against cathepsin D & - & + & - & - \\
\hline
\end{tabular}

$*+$ inhibitory effect; - lack of inhibition

Table 8. Differences in proteins sensitivity to cathepsin E and cathepsin D activity with supplements

\begin{tabular}{|c|c|c|c|c|c|}
\hline \multirow{3}{*}{ Protein } & \multicolumn{5}{|c|}{ Cathepsin } \\
\hline & $\mathbf{E}$ & D & $\mathbf{E}$ & D & E:D \\
\hline & \multicolumn{2}{|c|}{ Optimum pH } & \multicolumn{2}{|c|}{ Activity (\%) } & Ratio \\
\hline Bovine globin & 3.1 & 3.5 & 100 & 100 & 1.0 \\
\hline Human albumin & 2.5 & 4.0 & 153 & 1 & 153.0 \\
\hline Bovine albumin & 3.5 & 4.0 & 261 & 14 & 18.6 \\
\hline Bovine gamma-globulin & 3.0 & 3.0 & 1 & 3 & Approx. 0.3 \\
\hline Bovine casein & 3.0 & 3.0 & 98 & 32 & 3.0 \\
\hline
\end{tabular}

The optimum $\mathrm{pH}$ of cathepsin $\mathrm{E}$ in its activity towards albumin is $\mathrm{pH} 2.5$, while in the case of cathep$\sin \mathrm{D}$, it is 3.5. Besides, cathepsin $\mathrm{D}$ is quickly deactivated in $\mathrm{pH} 2.5$, especially at a temperature of $45^{\circ} \mathrm{C}$. Peptides soluble in TCA, released from albumin by cathepsin E, are determined with a microbiuret reagent [61]. For determination of cathepsin E activity, a $10 \%$ solution of human blood albumin is used. Albumin $(10 \mathrm{~g})$ is dissolved in distilled water, brought to $\mathrm{pH} 2.5$ with $1 \mathrm{~mol} / \mathrm{l} \mathrm{HCl}$ and complemented with water up to $100 \mathrm{ml} ; 0.5 \mathrm{ml}$ of the tested material is added to $0.5 \mathrm{ml}$ of albumin and incubated for $30 \mathrm{~min}$ utes at $45^{\circ} \mathrm{C}$. The reaction is stopped by adding $1 \mathrm{ml}$ of $4 \%$ trichloroacetic acid, following which the sample is incubated for 10 minutes at $45^{\circ} \mathrm{C}$ and centrifuged. $1.5 \mathrm{ml}$ of biuret reagent is added to $1 \mathrm{ml}$ of supernatant $\left(1.5 \mathrm{~g} \mathrm{CuSO}_{4} \times 5 \mathrm{H}_{2} \mathrm{O}\right.$ and 6.0 potassium sodium tartrate is dissolved in $500 \mathrm{ml}$ of distilled water, $300 \mathrm{ml}$ of $10 \% \mathrm{NaOH}$ is added, and the volume is complemented to $1,000 \mathrm{ml}$ with distilled water); after 30 minutes, extinction is read at $555 \mathrm{~nm}$. The control test is carried out by adding the substrate and the enzyme to trichloroacetic acid. The results are read from the calibration graph made using human blood serum.

Globin is also a frequently used substrate; it is used for making zymograms as well [7]. The optimum activity of cathepsin E towards globin occurs in $\mathrm{pH}$ 3.0, and cathepsin D - in pH 3.5.

Certain polypeptides, such as beta-endorphin and neurokinine A are much better substrates for cathe-
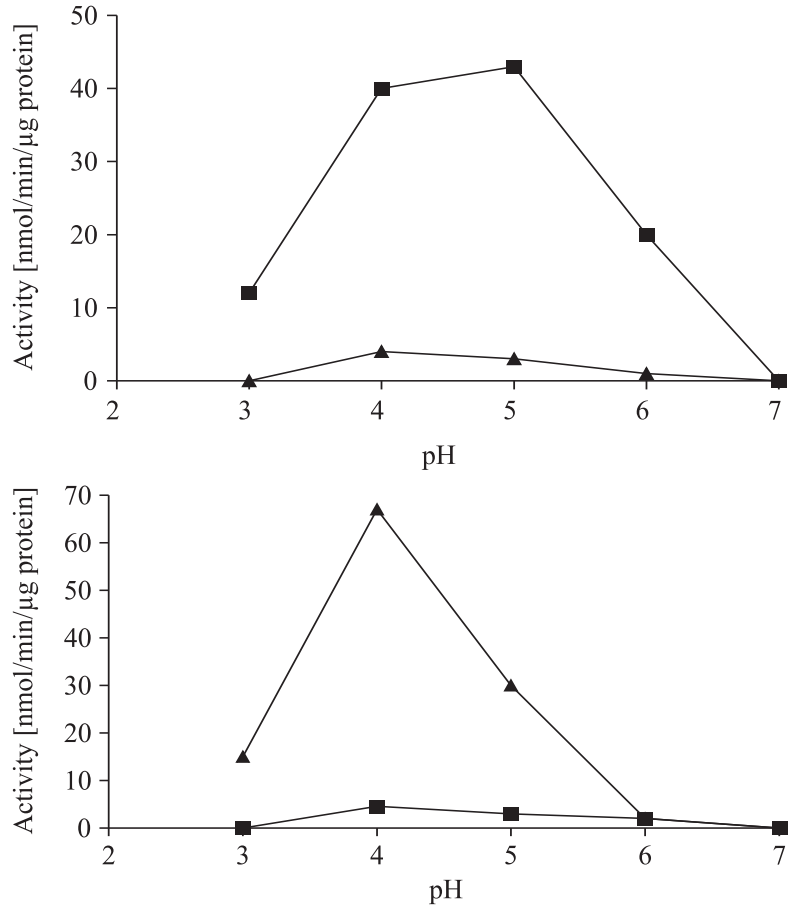

Figure 11. Hydrolysis of substance $\mathrm{P}(\mathbf{A})$ and $\beta$-endorophine (B) by cathepsin E ( $\square)$ and cathepsin D ( $\mathbf{(})$

psin E than proteins [14, 65]. Differences in the sensitivity of beta-endorphin and substance $\mathrm{P}$ to the activities of cathepsin E and cathepsin D are illustrated in Figure 11 [58].

Synthetic peptide chromogenic and fluorogenic substrates [29] are based on the sequence of cleavage sites 
Table 9. Hydrolytic activities of cathepsin E for bilogically active peptides in $\mathrm{pH} 5.0$

\begin{tabular}{|c|c|}
\hline Peptide & $\begin{array}{c}\text { Activity } \\
{[\mathrm{nmol} / \mathrm{min} / \mu \mathrm{g} \text { protein }]}\end{array}$ \\
\hline & Cathepsin E \\
\hline $\begin{array}{l}\text { Brain — gastrointestinal peptides } \\
\text { Substance P } \\
\text { Neurokinin A } \\
\text { Eledoisin } \\
\text { Kassinin } \\
\text { Cholecystokinin - octapeptide } \\
\text { Neuromedin C } \\
\text { Bombesin } \\
\text { Neurotensin }\end{array}$ & $\begin{array}{c}45.0 \\
22.5 \\
11.5 \\
3.2 \\
0.0009 \\
\mathrm{UC}^{*} \\
\mathrm{UC}^{*} \\
\mathrm{UC}^{*}\end{array}$ \\
\hline $\begin{array}{c}\text { Growth-factor fragments } \\
\text { Acidie FGF 102-111 } \\
\text { Basic FGF 106-120 }\end{array}$ & $\begin{array}{l}2.7 \\
1.5\end{array}$ \\
\hline $\begin{array}{l}\text { Opioid peptides } \\
\beta \text {-endorphin } \\
\text { Dynorphin A }\end{array}$ & $\begin{array}{c}1.8 \\
0.065\end{array}$ \\
\hline $\begin{array}{l}\text { Vasoconstrictor peptides } \\
\text { Porcine renin substrate } \\
\text { Human renin substrate } \\
\text { Big endothelin-1 }\end{array}$ & $\begin{array}{l}15.3 \\
0.63 \\
0.11\end{array}$ \\
\hline
\end{tabular}

* UC - uncleaved

in alpha2-Mg. The substrate Mca-Gly-Lys-Pro-Ile-Leu-Phe-Phe-Arg-Leu-Lys/Dnp/-D-Arg-NH is hydrolyzed both by cathepsin $E$ and by cathepsin D. Cathepsin $D$ is removed from the samples by means of immunoprecipitation with the use of specific antibodies. The remaining activity is cathepsin E. Synthetic peptide substrates Lys-Pro-Ile-Glu-Phe + Nph-Arg-Leu and Pro-Pro-Thr-Ile-Phe+Nph-Arg-Leu contain a p-nitrophenylalanine residue in position $\mathrm{P} 1$ ', where it serves the function of a chromogenic indicator group [66]. That allows for spectrophotometric determination, but there are some limitations: change of absorbance is only detected in $\mathrm{pH}$ over 6.0 and must be measured at the wavelength of $300 \mathrm{~nm}$ [66]. The measurements are carried out in $\mathrm{pH} 3.0-3.5$. The chromogenic peptide Mca-Gly-Lys-Pro-Ile-Leu-Phe + Plo-Arg-Leu-Lys/Dnp/-NH2 is cleaved by cathepsin $\mathrm{E}$ and cathepsin $\mathrm{D}$ but the former is active in $\mathrm{pH} 2.0$ and the latter is not active in such $\mathrm{pH}$ [29].

Concentration of cathepsin $\mathrm{E}$ is determined with the use of specific antibodies, by means of titration of the catalytic site with pepstatine and with the use of a calibration graph presenting the dependence of activity on the concentration of highly purified cathepsin E preparation [38].

\section{The role of cathepsin $\mathbf{E}$ in pathobiochemistry}

So far, no particular role of cathepsin $\mathrm{E}$ in the metabolism of proteins in normal tissues has been found. However, it is known that there are many document-
Conditions associated with cathepsin E-deficient mice

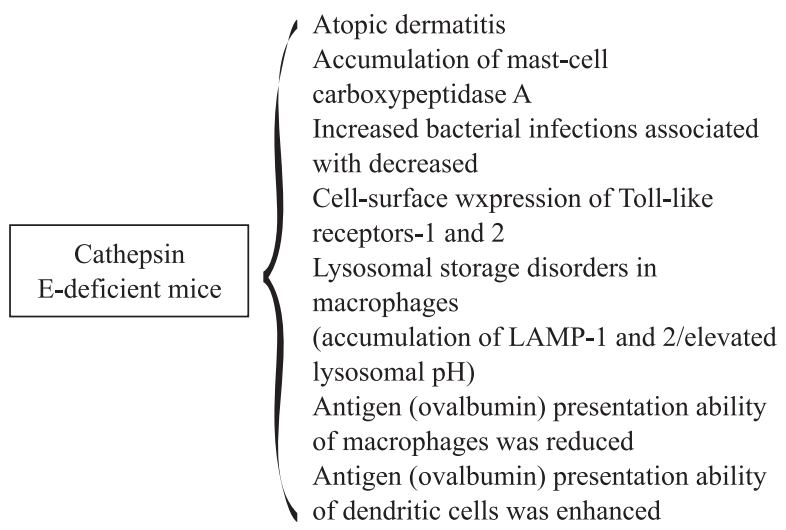

Conditions where overexpression of cathepsin $\mathbf{E}$ is observed

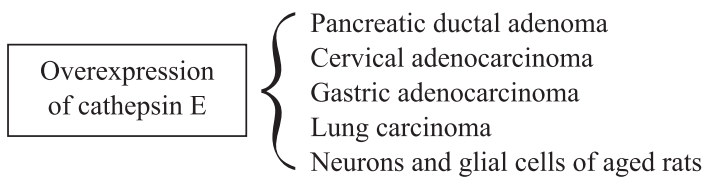

Effect of inhibition of cathepsin $\mathrm{E}$ by different inhibitors in immulogical cell-based assays

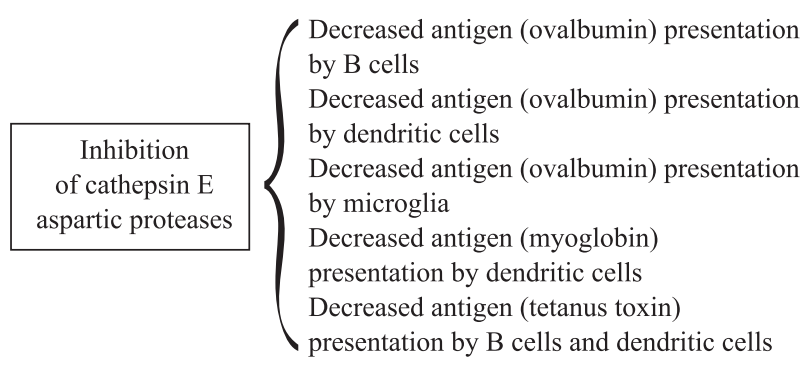

Figure 12. The role of cathepsin $\mathrm{E}$ in pathobiochemistry

ed pathological conditions in which overexpression of cathepsin E occurs. Cathepsin E acts towards many biologically active peptides (Table 9) [67]. The role of cathepsin $\mathrm{E}$ in pathobiochemistry is presented in Figure 12 [68].

Mice with a shortage of cathepsin E are often prone to atopic dermatitis. In humans with diagnosed atopic dermatitis, a decrease of cathepsin E activity in blood erythrocytes has also been observed. This may suggest that a shortage of cathepsin E may predispose one to the development of that disease [69].

An increased activity of cathepsin $\mathrm{E}$ has been observed in the case of proliferative diseases such as gastric carcinoma or cervical cancer [70-72]. The greatest attention, however, has been given to pancreatic duct adenocarcinoma, in the case of which cathepsin E can be treated as a diagnostic marker [73, 74]. Cathepsin E may be a promising marker in patients with pancreatic duct cancer. However, the invasive character of the method of taking pancreatic juice limits broader use of that method for routine controls.

In recent reports, a connection between cathepsin $\mathrm{E}$ and prostate gland cancer has been proved. Cathepsin $\mathrm{E}$ 
inhibits growth of the tumor and inhibits apoptosis in prostate cancer cells by releasing tumor necrosis factor [75]. Furthermore, inhibition of tumor growth by inhibition of angiogenesis, as well as strengthening immunological response, has been found [76]. An increased activity of cathepsin $\mathrm{E}$ in tumors causes increased expression of certain anti-angiogenic factors, including interleukin-12 and endostatin.

\section{References}

1. Lapresle C, Webb T. The purification and properties of proteolytic enzyme rabbit cathepsin $\mathrm{E}$ and further studies on rabbit cathepsin D. Biochem J. 1962;84:455-462.

2. Kay JTPJ. Cathepsin E. In: Barrett AJ, Rawlings ND, Woessner JF (eds.). Handbook of Proteolytic Enzyme. Elsevier Academic Press, London 2004;33-38.

3. Yonezawa S, Tanaka T, Muto N, Tani S. Immunochemical similarity between a gastric mucosa non-pepsin acid proteinase and neutrophil cathepsin E of the rat. Biochem Biophys Res Commun. 1987;144:1251-1256.

4. Samloff IM, Taggart, RT, Shiraishi T et al. Slow moving proteinase. Isolation, characterization and immunohistochemical localization in gastric mucosa. Gastroenterology. 1987;93:77-84.

5. Tarasova NI, Szecsi PB, Foltmann B. An aspartic proteinase from human erythrocytes is immunochemically indistinguishable from a non-pepsin, electrophoretically slow moving proteinase from gastric mucosa. Biochem Biophys Acta. 1986;880:96-100.

6. Yonezawa S, Tanaka T, Miyauchi T. Cathepsin E from rat nentrophils: its properties and possible relations to cathepsin D-like and cathepsin E-like acid proteinases. Arch Biochem Biophys. 1987;256:499-508.

7. Jupp RA, Richards AD, Kay J et al. Identification of the aspartic proteinases from human erythrocyte membranes and gastric mucosa (slow-moving proteinase) as catalytically equivalent to cathepsin E. Biochem J. 1988;254:895-898.

8. Cook M, Buhling F, Ansorge S, Tatnell PJ, Kay J. Pronapsin A \& B gene expression in normal and malignant human lung and mononuclear blood cells. Biochim Biophys Acta. 2002;1577:10-16.

9. Sakai H, Saku T, Kato Y, Yamamoto K. Quantitation and immunohistochemical localization of cathepsins $\mathrm{E}$ and $\mathrm{D}$ in rat tissues and blood cells. Biochim Biophys Acta. 1989;31:367-375.

10. Sastradipura DF, Nakanishi H, Tsukuba T et al. Identification of cellular compartments involved in processing of cathepsin E in primary cultures of rat microglia. $J$ Neurochem. 1998;70:2045-2056

11. Chain BM, Free P, Medd P, Swetman C, Tabor AB, Terrazzini N. The expression and function of cathepsin $\mathrm{E}$ in dendritic cells. J Immunol. 2005;174:1791-1800.

12. Solcia E, Paulli M, Silini E et al. Cathepsin E in antigen-presenting Langerhans and interdigitating reticulum cells. Its possible role in antigen processing. Eur J Histochem. 1993;37:19-26.

13. Finzi G, Cornaggia M, Capella $\mathrm{C}$ et al. Cathepsin $\mathrm{E}$ in follicle associated epithelium of intestine and tonsils: localization to $\mathrm{M}$ cells and possible role in antigen processing. Histochemistry. 1993;99:201-211.

14. Kageyama T, Moriyama A, Kato T, Sano M. Determination of cathepsins $\mathrm{D}$ and $\mathrm{E}$ and cells of rat, monkey and man by the assay with $\beta$-endorphin and substance $\mathrm{P}$ as substrates. Zool Sci. 1996;13:693-698.

15. Yonezawa S, Nakamura K. Species-specific distribution of cathepsin E in mammalian blood cells. Biochim Biophys Acta . 1991;1073:155-160.
16. Bennett K, Levine T, Ellis JS et al. Antigen processing for presentation by class $\mathrm{H}$ major histocompatibility complex requires cleavage by cathepsin E. Eur J Immunol. 1992;22:1519-1524.

17. Ueno E, Sakai H, Kato Y, Yamamoto K. Activation mechanism of erythrocyte cathepsin E. evidence for the occurrence of the membrane-associated active enzyme. J Biochem. 1989;105:878-882.

18. Azuma T, Liu W, Yander Laan DJ, Bowcock AM, Taggart RT. Human gastric cathepsin E gene. J Biol Chem. 1992;267: 1609-1614.

19. Tatnell PJ, Roth W, Deussing J, Peters C, Kay J. Mouse procathepsin E gene: molecular organisation and chromosomal localisation. Biochim Biophys Acta. 1998;1398:57-66.

20. Finley EM, Kornfeld S. Subcellular localization and targeting of cathepsin E. J Biol Chem. 1994;49:31259-31266.

21. Okamoto K, Hu H, Misum Y, Ikehara Y, Yamamoto K. Isolation and sequencing of two cDNA clones encoding rat spleen cathepsin $\mathrm{E}$ and analysis of the activation of purified procathepsin E. Arch Biochem Biophys. 1995;322:103-111.

22. Fowler SD, Tatnell PJ, Bur D, Kay J. Novel forms of cathepsin E. In: Aspartic Proteinases: Retroviral \& Cellular; 1998.

23. Tatnell PJ, Cook M, Kay J. An alternatively spliced variant of cathepsin $\mathrm{E}$ in human gastric adenocarcinoma cells. Biochim Biophys Acta. 2003;1625:203-206.

24. Aoki T, Takasaki T, Furukawa T, Morikawa J, Yano T, Watabc H. Conversion of cathepsin E to enzymatic unstable form in gastric cancer cells. Biol Pharm Bull. 1995;18:1522-1525.

25. Fowler SD, Kay J, Dunn BM, Tatnell PJ. Monomeric human cathepsin E. FEBS Lett. 1995;366:72-74.

26. Tatnell P. Cloning, expression and characterisation of murine procathepsin E. FEBS Lett. 1997;408:1,62-66.

27. Chou KC. Modeling the tertiary structure of human cathepsin-E. Biochem Biophys Res Commun. 2005;27:331:56-60.

28. Lapresle C, Puizdar V, Porchon-Bertolotto C, Jotikoff E, Tlirk V. Structural differences between rabbit cathepsin $\mathrm{E}$ and cathepsin D. Biol Chem Hoppe Seyler. 1986;367:523-526.

29. Yasuda Y, Kageyama T, Akamine A et al. Characterization of new fluorogenic substrates for the rapid and sensitive assay of cathepsin E and cathepsin D. J Biochem. 1999;125: 1137-1143.

30. Takeda-Ezaki M, Yamamoto K. Isolation and biochemical characterization of procathepsin $\mathrm{E}$ from human erythrocyte membranes. Arch Biochem Biophys. 1993;304:352-358.

31. Yamamoto K, Nakanishi H, Tsukuba T et al. Biosynthesis and trafficking of cathepsin E. In: Hopus-Have VK, Järvinen M, Kirschke H (eds). Proteolysis in Cell Function. IOS Press, Amsterdam 1997;215-222.

32. Thomas DJ, Richards AD, Kay J. Inhibition of aspartic proteinases by alpha 2-macroglobulin. Biochem J. 1989;259:905-907.

33. Yamamoto K, Marchesi VT. Purification and characterization of acid proteinase from human erythrocyte membranes. Biochim Biophys Acta. 1984;790:208-218.

34. Yamamoto K, Katsuda N, Kato K. Affinity purification and properties of cathepsin E-like acid proteinase from rat spleen. Eur J Biochem. 1978;92:499-508.

35. Yonezawa S, Tanaka T, Muto N, Tani S. Immunochemical similarity between a gastric mucosa non-pepsin acid proteinase and neutrophil cathepsin E of the rat. Biochem Biophys Res Commun. 1987;144:1251-1256.

36. Hara K, Fukuyama K, Sakai H, Yamamoto K, Epstein WL. Purification and immunohistochemical localization of aspartic proteinases in rat epidermis. JInvest Dermatol. 1993;100:394-399.

37. Takeda-Ezaki M, Yamamoto K. Isolation and biochemical characterization of procathepsin $\mathrm{E}$ from human erythrocyte membranes. Arch Biochem Biophys. 1993;304:352-358.

38. Kageyama T. Procathepsin E and cathepsin E. Methods Enzymol. 1995;248:120-136. 
39. Hill J, Montgomery DS, Kay J. Human cathepsin E produced in E. coli. FEBS Lett. 1993;326:101-104.

40. Tatnell PJ, Kay J. The influence of N-terminal fusion partners on the production and folding of recombinant human procathepsin E. Protein Pept Lett. 1997;4:397-404.

41. Tsukuba T, Hori H, Azuma T et al. Isolation and characterization of recombinant human cathepsin E expressed in Chinese hamster ovary cells. J Biol Chem. 1993;268:7276-7282.

42. Yamada M, Azuma T, Matsuba T et al. Secretion of human intracellular aspartic proteinase cathepsin E expressed in the methylotrophic yeast, Pichia pastoris and characterization of produced recombinant cathepsin E. Biochim Biophys Acta. 1994;1206:279-285.

43. Azim MK, Zaidi ZH. Molecular modelling of human procathepsin E: analysis of salt-bridge interactions between propeptide and enzyme segment. Biochem Biophys Res Comnun. 1999;264:825-832.

44. Rao CM, Scarborough PE, Kay J et al. Specificity in the binding of inhibitors to the active site of human/primate aspartic proteinases: analysis of P2-P1-P1'-P2' variation. J Med Chem. 1993;36:2614-2620.

45. Scarborough PE, Dunn BMW. Redesign of the substrate specificity of human cathepsin D. Protein Eng. 1994;7:495-502.

46. Arnold D, Keilholz W, Schild H, Dumrese T, Stevanovic S, Rammensee HG. Substrate specificity of cathepsins D and E determined by $\mathrm{N}$-terminal and $\mathrm{C}$-terminal sequencing of peptide pools. Eur J Biochem. 1997;249:171-179.

47. Hewitt EW, Treumann A, Morrice N, Tatnell PJ, Kay J, Watts C. Natural processing sites for human cathepsin E and cathepsin D in tetanus toxin: implications for $\mathrm{T}$ cell epitope generation. J Immunol. 1997;159:4693-4699.

48. Athauda SBP, Takahashi T, Inoue H, Ichinose M, Takahashi K. Proteolytic activity and cleavage specificity of cathepsin E at the physiological $\mathrm{pH}$ as examined towards the $\mathrm{B}$ chain of oxidized insulin. FEBS Lett. 1991;292:53-56.

49. Arnol D, Keilholz W, Schil H, Dumrese T, Stevanovic S, Rammensee G. Evolutionary conserved cathepsin E substrate specificity as defined by N-terminal and C-terminal sequencing of peptide pools. Biol Chem. 1997;378: 883-891.

50. Arnold D, Keilholz W, Schild H, Dumrese T, Stevanovic S, Rammensee G. Substrate specificity of cathepsins D and E determined by $\mathrm{N}$-terminal and $\mathrm{C}$-terminal sequencing of peptide pools. Eur J Biochem. 1997;249:171-189.

51. Keilova $\mathrm{H}$, Lapresle $\mathrm{C}$. Inhibition of cathepsin $\mathrm{E}$ by diazoacetyl-methyl ester. FEBS Lett. 1970;9:348-350.

52. Zaidi N, Kalbacher H. Cathepsin E: a mini review. Biochem Biophys Res Commun. 2008;367:517.

53. Jupp RA, Dunn BM, Jacobs JW et al. The selectivity of statine-based inhibitors against various human aspartic proteinases. Biochem J. 1990;265:871-878.

54. Bird JE, Waldron TL, Little DK et al. The effects of novel cathepsin E inhibitors on the big endothelin pressor response in conscious rats. Biochem Biophys Res Commun. 1992;182: 224-231.

55. Keilova H, Tomasek V. Effect of pepsin inhibitor from Ascaris lumbricoides on cathepsin D and E. Biochem Biophys Acta.1972; 284:461-464.

56. Kageyama T, Tatematsu M, Ichinose M et al. Developmentdependent expression of cathepsins $\mathrm{D}$ and $\mathrm{E}$ in various rat tissues, with special reference to the high expression of cathepsin E in fetal liver. Zoolog Sci. 1998;15:517-523.

57. Ng KKS, Petersen JFW, Cherney MM et al. Structural basis for the inhibition of porcine pepsin by Ascaris pepsin inhibitor. Nature Struct Biol. 2000;7:653-657.
58. Martzen MR, McMullen BA, Smith NE, Fujikawa K, Peanasky RJ. Primary structure of the major pepsin inhibitor from the intestinal parasitic nematode Ascaris suum. Biochemistry. 1990;29:7366-7372.

59. Shibata M, Sakai H, Sakai E et al. Disruption of structural and functional integrity of a2-macroglobulin by cathepsin. E Eur J Biochem. 2003;270:1189-1198.

60. Thomas D, Richards A, Kay J. Inhibition of aspartic proteinases by alpha-2- macroglobulin. J Biochem. 1989;259: 905-907.

61. Zaidi N, Herrmann T, Baechle D et al. A new approach for distinguishing cathepsin $\mathrm{E}$ and $\mathrm{D}$ activity in antigen-processing organelles. FEBS J. 2007;274:3138-3149.

62. Press EM, Porter RR, Cebra J. The isolation and properties of a proteolytic enzyme, cathepsin $\mathrm{D}$, from bovine spleen. Biochem J. 1960;74:501-514.

63. Kregar I, Turk V, Lebez D. Acid proteinase from the small intestinal mucosa of rats. Z Naturforsch B. 1967;9:992.

64. Kregar I, Turk V, Lebez D. Some properties of the cathepsin from the mucosa of rat colon. Z Naturforsch B. 1967; 22:1360.

65. Kageyama T, Ichinose M, Yonezawa S. Processing of the precursors to neurotensin and other bioactive peptides by cathepsin E. J Biol Chem. 1995;270:19135-19140.

66. Dunn BM, Scarborough PE, Davenport R, Swietnicki W. Analysis of proteinase specificity by studies of peptide substrates: The use of UV and fluorescence spectroscopy to quantitate rates of enzymatic cleavage. In: Dunn BM, Pennington MW (eds). Methods in molecular biology, Vol. 36: Peptide analysis protocols. Totowa, New Jersey: Humana Press Inc; 225-243.

67. Kageyam T. Rabbit procathepsin E and cathepsin E. Eur J Biochem. 1993;15,216:717-728.

68. Zaidi N, Hermann C, Hermann T, Kalbacher H. Emerging functional roles of cathepsin E. Biochem Biophys Res Commun. 2008;377:327-330.

69. Tsukuba T, Okamoto K, Okamoto Y et al. Association of cathepsin E deficiency with development of atopic dermatitis. J Biochem. 2003;134:893-902.

70. Matsuo K, Kobayashi I, Tsukuba T et al. Immunohistochemical localization of cathepsins D and $\mathrm{E}$ in human gastric cancer: a possible correlation with local invasive and metastatic activities of carcinoma cells. Hum Pathol. 1996;27:184-190.

71. Lin CK, Lai KH, Lo GH et al. Cathepsin E and subtypes of intestinal metaplasia in carcinogenesis of the human stomach. Zhonghua Yi Xue Za Zhi (Taipei). 2001;64:331-336.

72. Tenti P, Romagnoli S, Silini E et al. Cervical adenocarcinomas express markers common to gastric, intestinal, and pancreatobiliary epithelial cells. Pathol Res Pract. 1994;190:342-349.

73. Uno K, Azuma T, Nakajima M et al. Clinical significance of cathepsin $\mathrm{E}$ in pancreatic juice in the diagnosis of pancreatic ductal adenocarcinoma. J Gastroenterol Hepatol. 2000; 15:1333-1338.

74. Busquets L, Guillen H, DeFord ME et al. Cathepsin E is a specific marker of dysplasia in APC mouse intestine. Tumour Biol. 2006;27:36.

75. Kawakubo T, Okamoto K, Iwata J et al. Cathepsin E prevents tumor growth and metastasis by catalyzing the proteolytic release of soluble TRAIL from tumor cell surface. Cancer Res. 2007;67:10869-1087.

76. Shin M, Kadowaki T, Iwata $\mathbf{J}$ et al. Association of cathepsin E with tumor growth arrest through angiogenesis inhibition and enhanced immune responses. Biol Chem. 2007;388: $1173-1181$. 